\title{
A ESCOLA DE SALAMANCA E SUA TEORIA QUANTITATIVA DA MOEDA
}

\author{
Suelem Halim Nardo de CARVALHO ${ }^{1}$ \\ Karla Maria da SILVA²
}

RESUMO: A presente pesquisa buscou mostrar que existiu uma tradição intelectual, a Escola de Salamanca, que, inserida num contexto histórico de consolidação dos Estados Nacionais Modernos e de grande desenvolvimento comercial mundial, produziu um número significativo de obras voltadas para explicação das atividades comerciais e financeiras. Contemporâneos às políticas econômicas mercantilistas, os autores salmantinos, dentre outras contribuiçóes, se destacaram pelo desenvolvimento da teoria quantitativa da moeda que, na prática, significou uma compreensão monetária antagônica ao bulionismo.

PALAVRAS-CHAVE: escola de Salamanca; teoria quantitativa da moeda.

\section{THE SCHOOL OF SALAMANCA AND ITS QUANTITATIVE THEORY OF MONEY}

ABSTRACT: This research aimed to show that an existing intellectual tradition, the School of Salamanca, which, by being inserted in a historical context of consolidation of Modern Nation States and great commercial development worldwide, produced a significant number of works aimed at explaining commercial and financial activities. Contemporary to mercantilist economic politics, Salmantine authors, among other contributions, stood out for the development of the quantity theory of money, which, in practice, meant a monetary understanding antagonistic to bullionism.

KEYWORDS: Salamanca school; quantity theory of money.

\footnotetext{
1 Universidade Estadual de Maringá (UEM), Maringá - PR - Brasil. Mestre em História, professora Assistente. ORCID: https://orcid.org/0000-0002-0578-8664.suelemhalim@hotmail.com.

2 Universidade Estadual de Maringá (UEM), Maringá - PR - Brasil. Doutora em História, professora Adjunta. ORCID: https://orcid.org/0000-0002-1177-8171.kmsilva2@uem.br.
} 


\section{Introdução}

No contexto das grandes descobertas marítimas do século XVI, graças à chegada massiva de metais preciosos vindos das minas do México e do Peru, a Europa e, especialmente, a Península Ibérica experimentaram um aumento no valor das mercadorias que ficou conhecido como Revolução dos Preços (VILAR, 1982). Tal fenômeno, que provocou uma mudança significativa na estabilidade dos preços, fez com que os autores da Escolástica Tardia se debruçassem sobre os efeitos que a abundancia e a carestia das moedas produziam no funcionamento das economias. Em síntese, podemos afirmar que a Segunda Escolástica pertence à tradiçâo filosófica católica do final da Idade Média e início da Idade Moderna. De acordo com Culleton (2010, p. 5),

Ao nos referirmos à Escolástica, estamos nos referindo ao método de ensino teológico e filosófico desenvolvido nos primórdios da universidade durante a Idade Média, entre os séculos IX e XVII. No método escolástico debatiam-se questôes e opiniōes, fundamentando-as com a razão. Os escolásticos procuravam conciliar os sagrados ensinamentos da doutrina cristã com o platonismo e o aristotelismo. Esse termo não significa exclusivamente filosofia medieval nem religiosa. É um método de produção de conhecimento fundado na disputa, no confronto de perspectivas visando respostas sustentadas na razão. Quando falamos de Segunda Escolástica, nos referimos ao pensamento desenvolvido segundo a metodologia escolástica durante os séculos XVI e começos do XVII, durante os quais esta forma de pensamento alcança um grande nível intelectual. Seu principal foco de desenvolvimento, ainda que não o único, é a chamada Escola de Salamanca, movimento intelectual iniciado por Francisco de Vitória (1483-1546) e projetado por seus discípulos para diversos centros de ensino da Europa e América. (CULLETON, 2010, p. 5).

A época da Escolástica Tardia foi também a era do mercantilismo, um sistema que, apesar das variaçôes em relação às políticas econômicas adotadas por diferentes naçôes, grosso modo, caracterizou-se pela forte intervençáo estatal nas economias, sendo o bulionismo/metalismo (acúmulo de metais preciosos em solo nacional), na maior parte dos casos, uma prática constante. Neste artigo, será mostrado como os autores da Escola de Salamanca foram especialmente profícuos na produção de obras que, por suas conclusôes, questionavam a efetividade e mesmo a legitimidade do bulionismo. 
Tradicionalmente, as primeiras críticas ao bulionismo são identificadas com a Escola Fisiocrata ${ }^{3}$. De fato, François Quesnay ${ }^{4}$ (1984), por exemplo, questionou a veracidade do argumento muito utilizado pelos mercantilistas em relaçâo às vantagens do acúmulo de metais preciosos em território nacional (bulionismo). Ao pôr em cheque o real valor dos metais preciosos, Quesnay explicou que a moeda não era riqueza de uso, mas era somente, por assim dizer, um utensílio de comércio que era incorruptível, que não se desgastava, não perecia ao servir às compras e que após dezenas de anos e centenas de milhares de compras era igualmente existente e útil ao comércio. Assim, muito pouco dinheiro bastaria para ser possível realizar o comércio dos produtos. A moeda era apenas o denominador do preço das riquezas comerciáveis, nas compras e vendas, e só serviria idealmente no comércio. Nessa direção, a opulência de um Estado não consistia, pois, na quantidade de moeda, mas na abundância e no bom preço das riquezas comerciáveis. Se um reino era pobre, isto náo se devia, como se dizia vulgarmente, à falta de dinheiro, mas à falta de riquezas comerciáveis ou ao preço demasiadamente baixo dessas riquezas. Um Estado agricultor só poderia ser rico pela abundância das produçôes anuais e pelo bom preço de seus produtos (QUESNAY, 1984). Com efeito, náo era pela quantidade de dinheiro que um reino atingia um alto grau de prosperidade, mas pela venda dos gêneros de sua agricultura no exterior. Assim, seria sempre a abundância e o bom preço dos gêneros agrícolas que representavam a fonte do dinheiro. Mas, a moeda, em si mesma, seria apenas uma riqueza estéril sem o comércio. Ela só poderia, pois, tornar-se uma riqueza maior num reino na medida em que fosse convertida, com lucro, em riquezas comerciáveis compradas no estrangeiro. Assim, não seria sensato acumular moeda num Estado em prejuízo do crescimento das riquezas que o comércio proporcionava (QUESNAY, 1984).

Mas foi, sobretudo, com a Economia Política Clássica 5 que as críticas às praticas mercantilistas alcançaram maior desenvolvimento e sofisticação. Adam Smith, em A Riqueza das Naçôes, explicou que a riqueza e o dinheiro, no linguajar comum, eram considerados como sinônimos, sob todos os aspectos. Da

\footnotetext{
3 Os fisiocratas pertenciam à escola de pensamento político e econômico desenvolvida por um grupo de economistas franceses no século XVIII, que acreditava que a riqueza das nações era basicamente derivada do valor e da produtividade de suas terras.

4 François Quesnay (1694-1774), médico e economista francês, um dos mais importantes nomes da Escola Fisiocrata. Autor do Quadro Econômico, livro escrito por em 1759, que estabeleceu as bases da teoria econômica dos fisiocratas.

5 Segundo o dicionário organizado por Sandroni, a Economia Política Clássica "definiu claramente seu contorno científico integral, na medida em que passou a centralizar a abordagem teórica na questão do valor, cuja única fonte original foi identificada no trabalho, tanto agrícola como industrial. A Escola Clássica firmou os princípios da livreconcorrência, que exerceram influencia decisiva no pensamento econômico capitalista" (SANDRONI, 1989, p.96).
} 
mesma forma, acreditava-se que um país rico - assim como um indivíduo rico era aquele que tinha muito dinheiro. Nessa suposição, acumular ouro e prata em um país constituía o caminho mais rápido para enriquecê-lo (SMITH, 1996). Por conta dessa crença popular, Smith apontou que todas as naçôes da Europa se empenhavam, embora de forma inútil, em descobrir todos os meios possíveis de acumular ouro e prata em seus respectivos territórios. A Espanha e Portugal, proprietários das principais minas que forneceram esses metais à Europa, proibiram, sob penas rigorosas, totalmente a exportação de ouro ou impuseram pesadas taxas aduaneiras à respectiva exportação (SMITH, 1996).

Mas, segundo Smith (1996), tal política metalista era completamente ineficaz, uma vez que a quantidade de uma mercadoria qualquer que o trabalho humano poderia comprar ou produzir era naturalmente regulada, em cada país, pela demanda efetiva, ou seja, pela capacidade ou necessidade de consumo de cada regiáo. Porém, nenhuma mercadoria era regulada mais facilmente e com maior exatidão pela demanda efetiva do que o ouro e a prata (SMITH, 1996). Portanto, quando a quantidade de ouro e prata importada em um país superava a demanda efetiva, não havia vigilância ou controle do governo que conseguissem impedir sua exportação: "não há proibiçãa que consiga impedir a exportação, quando os particulares vêem vantagem na exportação" (SMITH, 1996, p. 418). Nem mesmo todas as leis sanguinárias da Espanha e de Portugal foram capazes de evitar a evasão do ouro e da prata excedentes desses países. As contínuas importaçóes de metais ultrapassavam a demanda efetiva da Espanha e Portugal, fazendo com que seu preço, nos países ibéricos, descesse abaixo do vigente nos países vizinhos (SMITH, 1996).

O contrário dessa situação experimentada pelos países Ibéricos também era verdadeiro, ou seja, se em algum país a quantidade de ouro e prata não fosse suficiente para atender à demanda efetiva interna, de forma a fazer subir o preço desses metais em comparação com os países vizinhos, o governo não precisaria preocupar-se em importar, pois naturalmente haveria uma afluência destes metais em território nacional. E se um governante tentasse impedir tal importação, não conseguiria fazê-lo. Portanto, nunca a preocupação do governo seria tão supérflua como quando estivesse voltada para vigiar a conservação ou o aumento da quantidade de dinheiro em um país (SMITH, 1996).

A liberdade de comércio, segundo Smith (1996), seria o meio mais eficaz de garantir a quantidade necessária de ouro e prata em um país. O livre comércio sempre asseguraria o ouro e prata que a nação tivesse condiçóes de comprar ou empregar: fosse para fazer circular as mercadorias, fosse para outras finalidades. A riqueza de uma nação não estava, portanto, na quantidade de metais preciosos 
que ela conseguia acumular, mas na quantidade e variedade de comércio que ela conseguia gerar. Assim, "Se a descoberta da América enriqueceu a Europa, não foi por causa da importação de ouro e prata," - uma vez que "em virtude da riqueza das minas americanas, esses metais baixaram de preço" (SMITH, 1996, p. 430) - , mas sim por causa da expansão comercial mundial que ela possibilitou.

Porém, a hipótese deste artigo é de que já com a Escola de Salamanca é possível encontrar uma visão sobre as causas do enriquecimento nacional mais afinada com o desenvolvimento comercial geral, com a circulação dos produtos e dos lucros internacionais, chegando ao que poderíamos chamar de um primeiro modelo econômico global e, principalmente, o questionamento do acúmulo de metais preciosos em solo nacional. No século XVI já estava claro para os escolásticos salmantinos que o grande acúmulo de metais preciosos por si só não significava o enriquecimento de um Estado.

Nessa direção, será mostrado que os autores da Escola de Salamanca, ao desenvolverem uma teoria quantitativa da moeda, podem ser entendidos como antagonistas das práticas mercantilistas, especialmente no que concerne ao bulionismo. Junto a isso, se consideramos tais discussóes desde um ponto de vista cronológico, não estaria errado interpretar a Escola de Salamanca como precursora da crítica ao mercantilismo - tendo em vista que a sua oposição às práticas e concepçôes próprias do sistema mercantilista é anterior ao surgimento da Escola Fisiocrata.

No Brasil, a quase totalidade dos manuais de História do Pensamento Econômico ainda não menciona as contribuiçốes da Escola de Salamanca para o desenvolvimento desta ciência. De modo geral, priorizam-se as discussóes relativas à fisiocracia e aos economistas clássicos como sendo as escolas fundadoras da ciência econômica. Mas, fora do Brasil já existe uma vasta bibliografia que evidencia como a Escola de Salamanca constituiu um momento fundamental que interliga os desenvolvimentos do pensamento econômico observados entre a Idade Média e a Idade Moderna ${ }^{6}$. Neste sentido, acreditamos que o presente trabalho contribuirá para o preenchimento de algumas lacunas ao chamar a atenção da fundamental importância da Escola de Salamanca para a História do Pensamento Econômico ${ }^{7}$.

\footnotetext{
6 Em um trabalho intitulado Aproximación Histórica al concepto Escola de Salamanca, o teólogo espanhol Miguel Anxo Pena González (2008) arrolou uma lista bibliográfica correlata ao tema de 340 páginas.

7 Dentre os autores que qualificam os membros da Escola de Salamanca como fundadores da ciência econômica citaremos apenas alguns, como Grice-Hutchinson (1952), Fuentes (2017), Fuertes (2002), Chafuen (1986), Gómez Camacho (1985), Rivas (1999) e Roover (1995).
} 
Para tanto, primeiramente, será realizada uma conceituação da chamada Escola de Salamanca. Em seguida, será realizada uma breve contextualização do período no qual os autores salmantinos estavam inseridos e, após, serão realizadas as análises dos textos desses autores, destacando as discussóes relativas à teoria quantitativa da moeda.

\section{A Escola de Salamanca: conceito e delimitação}

Em geral, os teólogos são conhecidos por escreverem obras de filosofia e teologia, mas as obras dos escolásticos tardios não ficaram restritas a estas áreas do conhecimento humano. Na verdade, os escolásticos do final da Idade Média e começo da Idade Moderna escreveram sobre os mais variados assuntos. Política, direito, relaçóes internacionais, economia, por exemplo, foram temas muito recorrentes entre os trabalhos dos dominicanos e jesuítas ibéricos, dos séculos XVI e XVII. Nessa direção, a chamada Escola de Salamanca - corrente filosófica nascida na Universidade de Salamanca ${ }^{8}$ - foi uma tradição muito importante, pois esteve na origem de uma plêiade de pensadores que se tornaram ilustres pela influência que exerceram no desenvolvimento de uma série de conhecimentos, inclusive na área do pensamento político e econômico?.

De acordo com a definição de Font de Villanueva (2006, p. 153), Escola de Salamanca "es la denominación que suele aplicarse a un grupo de juristas españoles del siglo XVI, vinculados a la universidad salmanticense y creadores de un cuerpo de doctrina sobre derecho natural, internacional y teoría monetária". Diante da pergunta: "¿Es lícito, [...], hablar de una "Escuela de Salamanca»?”, Grice-Hutchinson afirma que o termo Escola de Salamanca já está consagrado por várias geraçóes de historiadores, para "referirse especificamente a Francisco de Vitoria, sus colegas, sus discipulos y sus principales continuadores, asi en el campo económico como en el de las otras disciplinas a que dedicaron mayormente sus esfuerzos" (GRICEHUTCHINSON, 1989, p. 25).

Para Jesús Luis Paradinas Fuentes (2017, p. 1), reconhece-se como Escola de Salamanca um grupo de teólogos e juristas espanhóis “de los siglos XVI y XVII que renovaron el pensamiento escolástico tomista para responder a las nove-

\footnotetext{
8 A Universidade de Salamanca, localizada no município de Salamanca, Espanha, é a mais antiga da Península Ibérica. Como conjunto de escolas catedrais, foi criada em 1134 pelo rei Afonso VII, porém a fundação da Universidade, como tal, data do ano 1218 pelo rei Afonso IX. Em 1255 recebeu o título de universidade pelo Papa Alexandre IV.

9 Da Universidade de Salamanca, tentando explicar o fenômeno de uma prolongada alta no nível dos preços (a chamada Revolução dos Preços), saíram os teólogos e doutores em direito canônico salmantinos, os maiores representantes da Segunda Escolástica (REEDER, 2003).
} 
dades introducidas por el humanismo renacentista, el descubrimiento de América y la reforma protestante". Segundo Maria Idoya Zorroza (2013, p. 59) o termo "Escola" se refere a "un grupo de pensadores que, en torno a un fundador o fundadores, tienen unos elementos comunes, una metodología, una opción cientifica diferenciada, y una forma propia de realizar la especifica labor intelectual". Em consonância com esta definição, não se pode negar "la existencia clara de una Escuela, de su carácter teológico, que se centra en la particular revisión del tomismo que realiza Francisco de Vitoria (y junto a él Domingo de Soto) en Salamanca a partir de 1526" (ZORROZA, 2013, p. 62). Os trabalhos empreendidos pelos teólogos de Salamanca representam a fundação de uma escola tanto materialmente, com a atribuição de funçóes aos professores e aos alunos na Universidade, quanto temporalmente, com a chegada de Francisco de Vitória à Universidade de Salamanca (ZORROZA, 2013). Nas palavras da autora, desde:

[...] su inicio se ha considerado que habia un elemento especifico en el grupo de teólogos que, en la Universidad de la ciudad del Tormes, encabezaron varias de las cátedras de Teología entre 1526 y principios del siglo XVII, por lo que se ameritaría una consideración de "Escuela" en sentido estricto, al encontrarse en ellos notas diferenciales que señalan un modo propio de hacer teología en los autores que forman parte de ella. (ZORROZA, 2013, p. 59-60).

Ainda de acordo com Zorroza (2013, p. 61, grifo nosso), a determinação de que houve uma Escola de Salamanca em sentido estrito não a converte em uma instituição fechada, surgida como que espontaneamente, nem tão pouco encerra "líneas de diálogo tanto con su passado inmediatamente anterior como con su presente, ni, por supuesto, las lineas de continuidad y posibilidad abiertas hacia el futuro". Para além do núcleo dos autores que se definem como integrantes da Escola de Salamanca, "ésta tiene un área de proyección espacial y temporal en temas, orientaciones, planteamientos, etc." E esta área de projeção coexiste "con iniciativas coetáneas de gran fecundidad que harán cobrar nuevos cursos a las ideas presentes en el pensamiento ibérico de los siglos XVI y XVII' (ZORROZA, 2013, p. 63).

Segundo Juan Belda Plans (1999, p. 372), a definição de Escola de Salamanca envolve um conceito amplo, pois abarca o grupo de teólogos e juristas que ocuparam "cátedras en Salamanca, pero también en otras Universidades Europeas y Americanas”. O núcleo original da Escola formou-se em Salamanca, "pero a partir de ahi se expande hacia Europa (sobre todo Coimbra y Roma) y América (Méjico y Lima)". Além disso, seus membros não se limitam aos profes- 
sores universitários de Salamanca, mas também abarcam europeus (como Molina ou Suárez) "y americanos (como Veracruz o Acosta); tampoco son sólo teólogos sino que también se incluyen algunos juristas relacionados con Vitoria y Salamanca (como Azpilcueta o Covarruvias)".

Para Ignacio Jericó Bermejo (2012, p. 97), a Escola de Salamanca é um movimento estreitamente relacionado com a Universidade em si, mas que " $d e$ todas formas, es preciso reconocer que la desborda también”. Nessa direção, Bermejo julga apropriado o uso do termo Escola, já que um conjunto de teólogos da Universidade de Salamanca uniu-se em torno de uma doutrina comum, um pensamento coeso, que abarcava as especificidades e individualidades de cada autor.

Si se me preguntara ahora qué es en definitiva la Escuela de Salamanca, no dudaría un instante en decir que es la joya por antonomasia de la Ciudad del Tormes; mejor todavía, de la Universidad. Esa joya es sólo un grupo de teólogos que trabajaron y enseñaron la teología desde la unidad con vistas a la universalidad. Todos ellos se vieron animados por los mismos ideales $y$ propósitos. Entre ellos no prevalecieron las individualidades. Por eso, recibió este destacado grupo el nombre de la Escuela (con mayúscula, por supuesto) de Salamanca. (BERMEJO, 2012, p. 96).

Ainda de acordo Bermejo (2012, p. 105), a chegada de Francisco de Vitória $^{10}$ (1483-1546) à Universidade de Salamanca, em 1526, marcou o nascimento da Escola uma vez que foram os seus ensinamentos que propiciaram unidade filosófica ao conjunto de professores de Salamanca: "La vieja Universidad de la Ciudad del Tormes [...] dio [a Francisco de Vitória] la posibilidad de que aquellas sus enseñanzas fueran reconocidas y aprobadas por todos, profesores y alumnos, como doctrina común";

Para Juan Belda Plans (1999, p. 380) a Escola de Salamanca foi um movimento teológico do século XVI, integrado por um amplo grupo de três geraçóes de teólogos, catedráticos e professores da Faculdade de Teologia de Salamanca, "todos los cuales consideran a Francisco de Vitoria como el artifice principal del movi-

\footnotetext{
${ }^{10}$ Francisco de Vitória (1483-1546) foi um dos mais destacados teólogos espanhóis da escolástica tardia. Considerado por ampla literatura como fundador da Escola de Salamanca, teve como obra magna Comentário a Secunda Secundae de Santo Tomás. Nesta obra, Vitória desenvolve prolixa discussão sobre as questões de ordem moral e filosófica propostas por São Tomás de Aquino, com especial atenção para as discussões relativas à justiça comutativa. Nesse sentido, Vitória inaugura uma rica e complexa sintonização dos problemas propostos pelo aquinate com as transformações sociais e econômicas do inicio da era moderna. Sem trair a doutrina do grande doutor da Igreja, Vitória, porém, vai mais fundo nas discussões relativas ao justo preço e à questão dos juros, por exemplo. E ao aprofundar tais discussões cria uma tradição de pensamento econômico que será seguida por seus alunos.
} 
miento y siguen los cauces de renovación teológica abiertos por él, hasta principios del siglo XVII." De acordo com Miguel Anxo Pena González (2005, p. 69), os próprios membros da Escola de Salamanca tinham consciência de pertencimento ao movimento intelectual que os abarcava, de modo que "nadie puede negar la existencia clara de una Escuela, que viene configurada por un modo de hacer y pensar, donde la teología es el motor propio y singular que da sentido a la misma”. Seguindo a opinião dos demais especialistas, Pena González (2005) sustenta que a vinda de Francisco de Vitória para a Universidade de Salamanca (e a disseminação do seu método de ensino) representou a fundação dessa corrente de pensamento. Sobre as inovaçóes intelectuais trazidas por Vitória, Pena González afirma:

Era una nueva manera concreta de concebir la realidad del hombre, un ser humano que estaba en estrecha relación con la teología, como ciencia suprema y más importante en las aulas universitarias, pero una teología que, bebiendo de las sustanciosas aguas del humanismo, entendía ésta como una ciencia abierta, dinámica y da actualización política, conciliando perfectamente la investigación de carácter más positivo con la posibilidades aportadas por la recuperación de las lenguas clásicas, como complemento para una teología donde ya abundaba lo especulativo. (PENA GONZÁLEZ, 2005, p. 79).

Depois de Francisco de Vitória, Domingo De Soto ${ }^{11}$ despontou como o continuador da tradição salmantina, uma vez que "Soto vive la misma experiencia, que podría estar presente en Vitoria: la necesidad de la renovación urgente de la Escolástica, acción que se consolida en Salamanca" (PENA GONZÁLEZ, 2005, p. 84). Ainda de acordo com Pena González, delimitar o quadro de autores pertencentes à Escola de Salamanca não é tarefa fácil, já que listas com diferentes nomes são reproduzidas por estudiosos do tema. Entretanto:

Si intentásemos hacer una organización de los autores, tendriamos que partir de una división elemental, en la que habría dos momentos fuertes de Escuela, que ya frecuentemente se denominan como Primera y Segunda Generación y, a su vez, en esa primera escuela comprendería dos momentos: el fundacional, compuesto por los maestros de primera hora, y el segundo, por los discípulos directos de los maestros. (PENA GONZÁLEZ, 2005, p. 89).

\footnotetext{
${ }^{11}$ Domingo de Soto (1494 - 1560) foi um frade dominicano espanhol, professor de teologia na Universidade de Salamanca.
} 
Quanto à abrangência da Escola de Salamanca, Pena González afirma que seu magistério não se limitava à tarefa de docência universitária, mas se estendia a distintos âmbitos, desde estudos conventuais, publicaçóes de obras, como os frequentes e diversos serviços à Coroa, "donde se va haciendo reflexión teológica a partir de las necessidades y asuntos concretos que han de ser abordados y estudiados" (PENA GONZÁLEZ, 2005, p. 89). Por fim, Pena González (2005, p. 117) assevera não haver dúvidas de que a Escola de Salamanca faz "referencia directa a la Facultad de Teología, de la Universidad de Salamanca, aunque no de manera exclusiva, puesto que está abierta a infinidad de confluências".

De uma perspectiva mais restritiva, quanto à delimitação do âmbito material da Escola de Salamanca, encontramos os trabalhos de José García Barrientos (2011) que reduz a abrangência da Escola aos doutores dominicanos diretamente relacionados com as atividades intelectuais dentro dos muros do convento de San Esteban ${ }^{12}$.

Se a chegada de Francisco de Vitória à universidade de Salamanca (1526) é aceita pela comunidade de especialistas acadêmicos como o ano de nascimento da Escola, um pouco mais complexo é delimitar seu desaparecimento. Por exemplo, "Nació ciertamente la Escuela de Salamanca en 1526 y ella desapareció a lo largo del siglo XVII", é a resposta um tanto quanto vaga de Bermejo (2012, p. 105). Juan Belda Plans, de modo mais preciso, estabelece o ano da morte de Domingo Báńez ${ }^{13}$, 1604, como a data do encerramento da Escola de Salamanca. De acordo com Belda Plans, com o falecimento de Domingo Báñez a Escola de Salamanca entrou em uma fase de decadência e perda de unicidade intelectual, marcando, assim, o seu declínio.

En cuanto a los límites temporales [da Escola de Salamanca] en sentido estricto, abarcaría casi todo el siglo XVI y primeros años del XVII: desde la llegada de Francisco de Vitoria a la cátedra de Prima de Salamanca en el año 1526, hasta la muerte de Domingo Báñez en el año 1604. Posteriormente a esta última fecha, tras sus inicios y apogeo, se produce una decadencia paulatina en la que todavía se dejan sentir los efectos saludables de la teología renovada salmantina, pero sin que haya grandes figuras teológicas concatenadas entre si, como hasta ese momento. (BELDA PLANS, 1999, p. 383).

\footnotetext{
${ }^{12}$ Convento dominicano localizado dentro de um complexo integrado também pela Igreja de San Esteban, na cidade de Salamanca, Espanha, ao qual estavam ligados os doutores da Universidade de Salamanca.

13 Domingo Báñez (1528 -1604) teólogo espanhol, religioso da Ordem dos Frades Pregadores. Foi um dos mais ilustres defensores da doutrina de Tomás de Aquino.
} 
Posição semelhante à de Belda Plans foi adotada por Saranyana (2006, p. 514), que também destaca o encerramento das atividades intelectuais de Domingo Báńez (1576-1599) como sendo o fechamento de um ciclo dentro da Escola de Salamanca. Saranyana estabelece uma distinção entre duas geraçóes de pensadores pertencentes à Escola, que teriam marcado seu apogeu e declínio: a primeira geração teria se iniciado com Francisco de Vitória e permanecido até Mâncio de Corpus Christi (1526-1576), balizando uma fase apoteótica; e a segunda geração teria abrangido desde Bartolomé de Medina (1527-1580) até a aposentadoria de Domingo Báñez, no ano 1599, marcando o declínio da Escola de Salamanca.

\section{A Escola de Salamanca e seu contexto histórico}

Após essa breve discussão sobre a Escola de Salamanca (seu conceito e sua delimitação), e antes de voltar a atenção para os autores objetos dessa investigação, é preciso entender o contexto histórico no qual eles estavam inseridos. Para tanto, é preciso olhar para a Península Ibérica e para a sua posição de líder do Novo Mundo, de região que experimentou uma concentração inédita de problemas econômicos, políticos, sociais e culturais devidos às transformaçóes geradas pelas grandes descobertas marítimas dos séculos XV e XVI e que fomentaram a chamada Era Mercantilista.

Em primeiro lugar é preciso mencionar que o mercantilismo não existiu enquanto um corpo teórico formal e consistente, não podendo ser considerado uma doutrina política e econômica unificada. De fato, não houve autores mercantilistas que apresentassem um esquema geral do que seria um modelo de economia ideal, tal como se observa com a Escola Fisiocrata ou, mais tarde, com a Economia Política Clássica. O que se percebe durante o período que a historiografia convencionou chamar de mercantilista é um conjunto de ideias e práticas mais ou menos esparsas, que apresentam alguns pontos de convergência, a depender da região e do autor em questão. Em praticamente todos os manuais sobre o mercantilismo consultados é possível encontrar o destaque para as variantes do sistema entre os diferentes países ${ }^{14}$. É consenso acadêmico, portanto, a convicção de que a literatura e as políticas mercantilistas são demasiadamente diversas para serem agrupadas dentro de uma mesma categoria descritiva. De acordo com Julio L. Arroyo Vozmediano:

\footnotetext{
${ }^{14}$ Deyon (1985), por exemplo, afirma não existir um mercantilismo, mas, sim, vários mercantilismos (inglês, francês, holandês, espanhol etc.).
} 
[...] no se puede hablar con propiedad de un movimiento [mercantilista] ya que sus integrantes, básicamente, desconocian unos los trabajos de otros, y simplemente se enfrentaban a problemas parecidos y tenían un programa similar para procurar el desarrollo de sus respectivas economías nacionales. (VOZMEDIANO, 2017, p. 388).

Tendo em vista a relativa dificuldade de caracterização do sistema mercantilista, por conta da falta de unicidade teórica entre seus autores, Perdices de Blas (2003, p. 46) afirma que o mercantilismo foi um movimento de ideias e práticas muito esparsas no tempo e no espaço, entretanto duas características comuns impregnaram a literatura mercantilista de uniformidade: a) todos os mercantilistas participaram do mesmo problema: a situação de transformação econômica da Europa de seu tempo; b) todos buscavam o mesmo objetivo: contribuir para fortalecer o Estado-nação, a unidade básica de organização da Europa Atlântica daqueles tempos.

Ao examinar diversos autores que trabalham com o conceito de mercantilismo, Silva (2006) chega à conclusão de que a definição mais aceita é a de que o termo compreende um conjunto de ideias e práticas econômicas dos governos da Europa ocidental entre os séculos XV e XVIII, baseadas numa política de controle da economia pelo Estado. Silva ainda aponta que o conceito de mercantilismo vem acompanhado das ideias que se tornaram práticas comuns durante o período acima referido, como bulionismo/metalismo (acúmulo de metais preciosos em território nacional), balança comercial favorável (incentivo às exportaçôes em detrimento das importaçôes) e protecionismo alfandegário (taxação de produtos estrangeiros).

Partilhando da mesma perspectiva teórica, Hugon (1980) atribui o nome de mercantilismo às ideias e aos sistemas econômicos que se sucederam na Europa de 1450 a 1750, um período de tríplice transformação que serviu de ponto de partida para os tempos modernos: transformação intelectual (com o movimento renascentista), transformação política (constituição dos estados nacionais modernos) e transformação geográfica (em função das grandes descobertas marítimas).

Nessa direção, Deyon (1985) assevera que o mercantilismo foi uma forma de administração do tesouro real adotada pelos governos absolutistas da Europa a partir do século XV. Este tipo de organização se estabeleceu porque respondia ao mesmo tempo aos interesses de grandes mercadores e às necessidades financeiras do rei. Isto é, foi um sistema que veio atender às demandas das jovens monar- 
quias juntamente com os interesses dos mercadores, que se tornavam cada vez mais importantes para a sociedade moderna.

Para Maurice Dobb (1983), o mercantilismo foi um conjunto de ideias e práticas econômicas que caracterizou a história econômica europeia e, principalmente, a política econômica dos Estados modernos europeus durante o período situado entre os séculos XV e XVIII. E, mais importante, um sistema de "exploração regulamentado pelo Estado e executado por meio do comércio, que desempenhou papel importante na adolescência da indústria capitalista: foi, essencialmente, a política econômica de uma era de acumulação primitiva" (DOBB, 1983, p. 149).

Definição esta que Falcon (1996, p. 9) corroborou, ao afirmar que "o mercantilismo, [...] foi o produto das condiçóes especificas de um determinado período histórico do Ocidente, caracterizado pela transição do feudalismo ao capitalismo". Além disso, foi época de "profunda conexão, da quase impossível dissociação, entre o político e o econômico, a qual constitui uma das principais características da época situada entre o final da Idade Média e o início da Revolução industrial" (FALCON, 1996, p. 17).

De acordo com Gustavo Arce (2013, p. 7), os autores mercantilistas analisaram e interpretaram a "chamada renovação econômica", ou a "larga marcha rumo ao capitalismo": processos de mutação histórica complexos que "comprenden varios siglos, en donde se imbrican la riqueza del Principe, la conquista y el pillaje colonial (fines del siglo XV y todo el XVI) con la formación de las burguesias mercantiles y bancarias (siglo XVI)." Com a construçáo dos Estados modernos, se multiplicam e se intensificam os intercâmbios econômicos; o modelo societário ocidental se expande e atinge a escala global; se desenvolvem e implementam novas técnicas de produção de transporte e de guerra; "surgen nuevas ideas y visiones del Mundo, de las relaciones humanas y del Hombre con la Naturaleza" (ARCE, 2013, p. 7).

A partir do século XV, com maior ou menor êxito e/ou frequência, praticamente todas as monarquias europeias enveredaram pelo caminho do mercantilismo. A preocupação com o acúmulo de metais preciosos em território nacional, com a balança comercial favorável, com o desenvolvimento de manufaturas e com a taxação de produtos estrangeiros, tornaram-se constantes em toda a Europa entre os séculos XVI e XVIII. É ponto pacífico entre os estudiosos que, por trás de tal sistema mercantilista, havia uma vontade de unificação territorial e de concentração do poder político. A era mercantilista foi também a época de formação do Estado Nacional Moderno, de modo que o mercantilismo servia tanto aos objetivos políticos quanto aos objetivos econômicos. Ambas as balan- 
ças (poder político e poder econômico) precisavam ser equilibradas. Era crença geral durante a vigência do sistema mercantilista a ideia de que a força militar era necessária como meio de aumentar e proteger a riqueza nacional. Desse modo, o mercantilismo, apesar de apresentar variantes de país para país, esteve sempre associado ao projeto de um Estado poderoso e à consolidação de uma nação forte capaz de se impor em relação aos demais Estados por meio do crescimento econômico. Nessa conjuntura, as coroas ibéricas são especialmente lembradas, tendo em vista as vastas áreas coloniais que estavam sob seus domínios e que serviram de instrumentos para execução de suas pretensóes de poder.

Após alguns séculos de hegemonia (que variou de regiáo para região, como já destacado), as ideias mercantilistas encontraram seus limites e, consequentemente, foram superadas. Tradicionalmente, os fisiocratas são identificados como sendo os primeiros a criticarem o sistema mercantilista na Europa. De fato, a chamada Escola Fisiocrata fez das políticas regulamentistas, metalistas e industrialistas seus principais alvos de ataques. Mas, a seguir, será mostrado que algumas discussóes que serviriam de argumentos para as críticas da fisiocracia ao mercantilismo (e mesmo para as da Economia Política Clássica) já estavam presentes nos trabalhos dos teólogos da Escola de Salamanca. Esse é o caso das discussóes relativas à teoria quantitativa da moeda, por exemplo ${ }^{15}$.

\section{A teoria quantitativa da moeda salmantina}

Segundo Reeder (2003) podemos considerar os autores da Escolástica Tardia como os precursores da teoria quantitativa de moeda ${ }^{16}$. O fato de terem sido os primeiros a lidarem com os problemas relativos à oferta monetária ocorreu porque desde o fim do Império Romano até o final da Idade Média a Europa não experimentava um problema forte em relação à inflaçáo. De acordo com Fuentes (2017), a relativa estabilidade monetária que a Europa medieval pôde experimentar sofreu um grande abalo a partir do momento em que as grandes

\footnotetext{
${ }^{15}$ Para o presente artigo, interessa apenas a discussão sobre a teoria quantitativa da moeda presente na Escola de Salamanca. Mas, além desse tema, é possível encontrar entre os autores salmantinos várias discussões a respeito da importância do comércio para a organização das sociedades; discussões sobre justo preço e sobre o valor subjetivo das mercadorias; críticas aos monopólios; legitimação da prática do empréstimo de dinheiro a juros; defesa da propriedade privada, etc., que podem ser consideradas como discussões precursoras das ideias que deram origem às escolas de economia posteriores. Como evidenciamos, quando cotejamos as explicações dos autores salmantinos com as explicações da Escola Fisiocrata ou da Economia Política Clássica para os problemas econômicos, vemos que muitos argumentos usados por estas duas últimas escolas de economia são reproduções de ideias tradicionais da Escola de Salamanca.

${ }^{16}$ De acordo com a teoria quantitativa da moeda, tal como defendida pelos economistas monetaristas do século XX, o nível dos preços é determinado pela quantidade de moeda em circulação e pela sua velocidade de circulação.
} 
navegaçóes dos séculos XV e XVI alargaram exponencialmente as rotas comerciais e interligaram regióes até então desconhecidas.

La primera consecuencia de las masivas llegadas de metales preciosos desde América fue el importante y continuo aumento de los precios de las mercancias, primero en España y después en el resto de Europa, hasta el punto de que los precios se triplicaron en el siglo XVI. Estas tasas de inflación, que en nuestros tiempos pueden parecer normales, no lo eran para los contemporáneos, acostumbrados a una mayor estabilidad de los precios. (FUENTES, 2017, p. 4).

De acordo com Rivas (1999, p. 139) a afluencia masiva de "metales preciosos a la península [Ibérica] tuvo un efecto inflacionista en la economía, que bien pronto fue apreciado por la gente de la calle, y analizado por los maestros universitarios". Gómez Rivas considera que Martín de Azpilcueta (1492-1586), através da publicação de seu Comentario Resolutorio de Cambios (1556), tenha sido o precursor de "la Teoría Cuantitativa del dinero" (RIVAS, 1999, p. 139), que, basicamente, afirmava que um aumento na quantidade de moeda em circulação em determinada região fazia subir os níveis dos preços. Algo muito semelhante foi afirmado por Fuentes (2017, p. 4) ao dizer que muito antes de a moderna teoria quantitativa da moeda ser formulada "algunos autores habian ya enseñado que entre las causas que explicaban los cambios del valor del dinero estaba su abundancia o escasez", sendo essa a postura de Martín de Azpilcueta quando esteve tratando das causas que faziam subir ou baixar o valor do dinheiro, por exemplo. Ainda de acordo com Fuentes (2017), no momento em que Azpilcueta publicava seu Comentario Resolutorio de Cambios era já uma realidade conhecida o fato de o dinheiro valer mais onde era escasso e menos onde superabundava. "La novedad teórica de Azpilcueta consistió en afirmar que la abundancia de dinero subia el precio de las mercancías y de los salarios mientas que la escasez los bajaba" (FUENTES, 2017, p. 4-5).

Na sequência será realizada uma análise da obra Comentario Resolutorio de Cambios, de Martín de Azpilcueta ${ }^{17}$, que permitirá a visualização a sua teoria quantitativa da moeda e evidenciará suas consideraçóes a respeito das políticas de acúmulo de metais preciosos em território nacional.

Diante da elevação dos preços, do ápice da movimentação monetária e da especulação cambiária, Martín de Azpilcueta foi paulatinamente conhecendo

\footnotetext{
${ }_{17}$ Também conhecido como Dr. Navarro, Matín de Azpilcueta Navarro pertencia à ordem dos jesuítas. Lecionou nas universidades de Salamanca, Coimbra e Toulouse. Dentre suas principais obras estão Comentario Resolutorio de Cambios e Manual de Confessores y penitentes.
} 
as necessidades de seu tempo e desenvolvendo a relação causal principal entre dinheiro (valor), sua abundância ou escassez, e mercadorias e salários, erigindo uma verdadeira teoria do valor do dinheiro que abarcava ideias que já eram correntes, mas que foram polidas, aperfeiçoadas e desenvolvidas, conseguindo, assim, uma teoria bastante sólida e eficiente para explicar os casos concretos que os problemas monetários fomentavam naquele momento ${ }^{18}$. Em relação aos motivos pelos quais o valor das moedas poderia baixar ou subir, Azpilcueta (1965, p.74) era claro: primeiramente, "es de haber gran falta y necesidad o copia de ép". Isto porque, o dinheiro "vale más donde o cuando hay gran falta de él, que donde hay abundancia" (AZPILCUETA, 1965, p. 74). Assim como as mercadorias se tornam mais caras nos momentos em que se tornam escassas, "el dinero, en cuanto es cosa vendible, trocable o conmutable por otro contrato, es mercadería, [...] luego también se encarecerá con la mucha necesidad y poca cantidad de él". Isso, basicamente, acontecia porque quando o dinheiro escasseava maior se tonava seu poder de compra, "mas cosas vendibles se hallan por um tanto a dinero" (AZPILCUETA, 1965, p. 78).

Até neste ponto as constataçôes do Dr. Navarro não são originais, pois outros autores já haviam percebido que quando o dinheiro superabundava, seu valor diminuía, e, pelo contrário, quando a moeda escasseava, ocorria uma valorização proporcional da mesma. $\mathrm{O}$ ponto de originalidade da argumentação de Azpilcueta vem na sequência, ao afirmar que a maior ou menor quantidade de dinheiro em um determinado espaço e período de tempo não afetava apenas a valorização da moeda e das mercadorias, mas também interferia no nível dos salários (na remuneração da mão-de-obra). Com isso, levava a questão da flutuação dos níveis gerais dos preços para outro patamar de complexidade.

[...] siendolo al ygual en las tierras do ya gran falta de dinero, todas las otras cosas vendibles, y aun las manos y trabajos de los hombres se dan por menos dinero que do ay abundancia del; como por la experiencia se vee que en Francia, do ay menos dinero que en España, valen mucho menos el pano, vino, paños, manos, y trabajos; y aun en España, el tiempo, que avia menos dinero, por mucho menos se daban las cosas vendibles, las manos y trabajos de los hombres, que despues que las Indias descubiertas la cubrieron de oro y plata. (AZPILCUETA, 1965, p. 74-75).

\footnotetext{
${ }^{18}$ Na opinião de Martín Martín (2012), a inovação no que se refere à teoria monetária promovida pelos autores salmantinos foi a de que para eles o nível de preços não seria somente determinado pela qualidade da moeda (concepção monetária medieval), mas também por sua quantidade em circulação.
} 
Neste trecho vê-se claramente que para Azpilcueta a causa da instabilidade no nível dos preços que a sociedade espanhola vivenciava naquele momento encontrava-se na chegada massiva até a Península Ibérica de ouro e prata das minas do Peru e do México. Ao se debruçar sobre o problema da desvalorização da moeda e das variaçóes no nível dos preços, Azpilcueta percebeu que a política de acúmulo de metais preciosos em território nacional era responsável por uma série de inconvenientes geradores de instabilidades e inseguranças econômicas e sociais que afetavam a estruturação da sociedade como um todo.

As reflexôes monetárias do autor em foco o levaram a perceber que o dinheiro (expresso através do valor das mercadorias e do nível dos salários) valia mais quando havia escassez do que quando havia abundância dele, confrontando a compreensão tradicional da época (mercantilista) que partia do pressuposto de que a escassez da moeda impedia o enriquecimento de uma região. Isto é, era ideia corrente no século XVI, na maior parte das naçóes, a noção de que sem grandes quantidades de ouro e prata uma sociedade não poderia ser rica. As constataçóes de Azpilcueta sobre as consequências do grande afluxo de metais preciosos até a Espanha levaram-no a concluir que o acúmulo de ouro e prata de per si em uma determinada região não produzia riqueza, mas, ao contrário, poderia gerar uma série de instabilidades, flutuaçóes no nível geral dos preços, que afetava não apenas o valor do dinheiro e das mercadorias, mas atingia também o preço da mão de obra dos trabalhadores, ao fazer baixar o salário devido ao efeito inflacionário (é importante lembrar que Azpilcueta não utilizava o termo inflação para expressar a perda do valor de compra do dinheiro frente ao aumento de moedas circulantes. Essa expressão (inflação) só aparece bem mais tarde, no século XIX). Em resumo, sobre a teoria monetária de Azpilcueta, é possível inferir que nas naçóes onde havia uma grande escassez de moeda todos os outros bens vendáveis, e mesmo o trabalho, eram trocados por menos moeda do que quando e onde esta era abundante. A razáo disso era que a moeda valia mais quando e onde era escassa do que quando e onde era abundante.

Veja-se agora outro autor da Escola de Salamanca, Tomás de Mercado ${ }^{19}$ (1530?-1576) e sua obra magna, Suma de Tratos y Contratos $(1571)^{20}$. Na primeira parte da Suma, Mercado escreve brevemente sobre as origens do comércio, explicando que pelo fato de não terem condiçóes de produzir todos os alimentos e mercadorias que lhes eram necessárias e/ou que lhes convinham, os homens

\footnotetext{
${ }_{19}$ Nascido em Sevilha, o teólogo Tomás de Mercado entrou para a ordem dos dominicanos em 1553.

${ }^{20}$ De acordo com Fuentes (2017, p. 5), Mercado, ao distinguir "entre el valor nominal y la estima del dinero, expone con mayor perfección la teoría cuantitativa al establecer un orden de estimación, que va de menos a más, entre las Indias, España y el resto de Europa."
} 
começaram a trocar uns com os outros o que lhes era abundante por aquilo que lhes faltava. "Daban trigo por aceite, vino por lienzos, paños por sedas, casas por heredades, ovejas por potros", sendo este "el primer contrato y negociación que hubo en el género humano" (MERCADO, 1975, p. 129). Com o tempo esta forma de negociação (chamada escambo) mostrou seus limites, o que possibilitou o surgimento de uma forma mais ampla e mais fácil de realizar a aquisição de mercadorias: a compra com o uso de moeda. O motivo pelo qual, na maior parte dos casos, o ouro e a prata foram os metais escolhidos para a fabricação da moeda estava ligado ao fato de serem metais incorruptíveis. Com a invenção da moeda, eis que se tornava mais evidente a função do mercador, cuja existência era muito antiga e que, segundo Mercado, "cuasi comezaron luego que el mundo se crioo" (MERCADO, 1975, p. 132). A função do mercador sempre foi muito estimada por causa de sua utilidade para todos os povos, uma vez que cabe a ele a arte de prover "las ciudades y reinos de infinita variedade de cosas que ellos en sí no tienen, trayendo las de fuera, tales que no sierven solo de regalo, sino muchas veces necesarias para la misma conservación de la vida" (MERCADO, 1975, p. 132).

Embora Tomás de Mercado fosse da opiniâo de que o governo tinha a obrigação moral de taxar o preço dos produtos essenciais para a manutenção da vida humana (como o trigo, por exemplo), impedindo com isso que o povo fosse extorquido pela ganância dos mercadores, ele acreditava que, em geral, a interferência dos governantes na economia por meio da taxação dos preços resultava em um mal maior do que aquele que supostamente estariam combatendo. Isto porque se os mercadores ficassem expostos a incorrer em prejuízos em suas negociaçóes, eles não venderiam seus produtos (o que geraria a carestia desse mesmo determinado bem de consumo) ou, então, venderiam secretamente por um valor maior do aquele tabelado pelo governo (MERCADO, 1975). Além disso, o preço justo das mercadorias, naturalmente - excetuadas as trapaças e manobras ludibriarias, como mercadorias viciadas e acordos escusos entre mercadores para manterem o preço elevado - "es mas variable (según la experiência enseña) que el viento". Assim, "lo que ayer valía cincuenta ducados (como la cochinilla) vale hoy treinta, o porque llegó mucha de México, o porque se escribió a Florencia, no habia pasaje a Turquia, o por otras dos mil ocasiones, que todos sabemos, y parte dellas se escribirán." (MERCADO, 1975, p. 177).

Sendo os preços tão variáveis devido às circunstâncias que se transformavam a todo o momento e às quais todos estavam submetidos, a taxação dos preços das mercadorias poderia gerar uma cadeia de obstáculos aos produtores e mercadores, impedindo-os de lucrarem com seus ofícios. Para o dominicano de Sevilha era uma questão de justiça que os mercadores pudessem auferir algum 
lucro sobre seus negócios tendo em vista todos os riscos, perigos e desgastes por eles experimentados em suas viagens e transaçóes. Uma vez que todos dependiam de outros para poderem viver em comunidade, era evidente que o mercador exercia uma função importante e até necessária para o bem comum (MERCADO, 1975).

Tomás de Mercado entendia que o ouro e a prata, em todos os lugares, eram tidos "por una especie de mercadería, y crece, y baja su valor por las mismas causas que la ropa ${ }^{21}$ ” (MERCADO, 1975, p. 264). Mas a moeda não era qualquer mercadoria, era a medida de valor e, por isso, instrumento de troca, de todas as outras mercadorias. Sendo uma peça tão importante dentro de uma determinada estrutura social, "se ha de suponer que entre muchas cosas sumamente necesarias al buen gobierno, y tranquilidad del reino, una es que el valor y ley de la moneda, y aun su cuño, y senãl sea durable, y cuán invariable ser pudiere" (MERCADO, 1975, p. 264). Pois, para que haja estabilidade nos preços e, consequentemente, a manutenção da dignidade do dinheiro "es regra universal, y necesaria que ha de ser cualquier medida fija, cierta, y permanente" (MERCADO, 1975, p. 265). De modo que todas as outras coisas podem e devem mudar, "pero la medida es menester que permanezca, porque por ella como por señal inmovible, conocemos cuánta es la mudanza, y variedad de las otras" (MERCADO, 1975, p. 265). Na sequência, Mercado faz uma comparação do dinheiro com o relógio, que, para ter utilidade, precisa de constância e precisão na marcação do tempo que é, por sua natureza, variável.

Tanto y más se requiere esta consistencia y perpetuidad en el dinero, que es medida de gran importancia, cada día se varía el valor en lo restante, lo que hoy vale caro, mañana baja. Y cuán necesario es al convicto, y trato humano, que sea asi, y se mude el precio en la ropa, y bastimentos, porque todos ganen, y gusten de vender, y comprar. Unas veces los vendedores por el interés, otras los compradores con su barato, tan necesario es, que la moneda no crezca, ni decrezca, ni la suban, ni la bajen, si pudiere, en doscientos años. Y que haya uno caso en la república, medio divina, y consagrada, a que no sea lícito llegar, ni hablar en su mudanza. (MERCADO, 1975, p. 265).

A alteração do valor da moeda gerava efeitos perniciosos na sociedade, efeitos econômicos e sociais da inflação e deflação. "Porque bajar y subir la moneda, dice, es aumentar o disminuir la hacienda de todos" (MERCADO, 1975, p. 265).

\footnotetext{
${ }^{21}$ A palavra ropa aparece na Suma de Tratos y Contratos com o sentido análogo ao de mercadoria.
} 
Sendo fundamental para a estabilidade da república e para o bem comum que o "principe que tiene la suma potestad no lo mude [o valor da moeda], no llegue a ello, cuanto atrevimiento, y perdición es, que lo muden los particulares por su antojo, y albedrio" (MERCADO, 1975, p. 266).

É importante destacar que Tomás de Mercado condenava como sendo uma prática contra a nação e contra o povo a alteração proposital do valor da moeda pelo governo. Isto é, criticava as políticas de intervenção monetária. Outra situação bem diversa, e que se dava de modo natural, era a diferença de apreciação que a moeda adquiria dependendo da regiáo e da circunstância por conta da estimação subjetiva das pessoas. $\mathrm{O}$ autor distinguia, assim, o valor nominal (que deveria ser fixo) do valor subjetivo (que era variável). Essa mudança de valor relativa à estimação subjetiva de local para local não era algo danoso ou mesmo que pudesse ser combatido ou evitado, mas uma realidade perfeitamente normal e condizendo com a natureza mesma do dinheiro.

$Y$ para entenderla [a diversa estimação da moneda], porque es muy buena, es de advertir no ser lo mismo el valor y precio del dinero y su estima. Ejemplo clarisimo es de esto: que en Indias vale el dinero lo mismo que acá, conviene a saber, un real treinta y cuatro maravedis, un peso de minas trece reales, y lo mismo vale el España. Más, aunque el valor y precio es el mismo, la estima es muy diferente entrambas partes, que en mucho menos se estima en Indias que en España. La calidad de la tierra y su disposición lleva de suyo que, en entrando uno en ella, se le engendra un corazón tan generoso en esta tecla que no tiene una docena de reales en más que acá, a modo de decir, una de maravedis. Tras las Indias, do en menos se tiene es en Sevilla, como ciudad que recibe en sí todo lo bueno que hay allá; luego, las demás partes de España. Se estima mucho en Flandes, en Roma, en Alemania, en Inglaterra. (MERCADO, 1975, p. 327).

A causa dessa variação em relação à apreciação e estima da moeda conforme a região era "de tener gran abundancia o penuria de estos metales, y como en aquellas partes [Índias] nace y se coge, se tiene en poco, que aun los hombres, según el refrán, no se honran ni se estiman comúnmente en su patria" (MERCADO, 1975, p. 327).

Veja-se mais um trecho onde Mercado expóe claramente a sua teoria quantitativa da moeda ao estabelecer uma ordem de estimação progressiva da moeda entre as Índias, Espanha e o resto de Europa, que reflete com perfeição a corre- 
lação entre a abundância ou escassez da moeda e sua correspondente menor ou maior estima:

[...] el primero es que los cambios modernos, se fundan en la diversa estimación del dinero, como se entienda que ha se ser universal, de todo un reino, o provincia, o universidad, no particular de dos, o tres, o cincuenta necesitados en el pueblo, sino según los ejemplos puestos declaran, en toda una república, como vemos, que en toda Flandes, en toda Roma, se estima en más que en toda Sevilla, y en Sevilla más que en Indias, y en Indias, más que en Santo Domingo que en Nueva España, y en Nueva España más que en Perú. Consta y parece lo que dije, si ponemos los ojos en esta negociación. Nunca en cambios se llevan tan grandes intereses, como en los que se hacen a partes, do es evidente se precia mucho la moneda. Los de mayor ventaja son los de Flandes, y Roma aquí, do consta que se tiene en más que en otras partes. Lo cual es buena señal, que a esta diversa estimación tienen ojo los cambiadores y cambios. Lo segundo, de Sevilla a Medina y a Lisboa, y a cualquier parte, lo que hace bajar, o subir la plaza es la abundancia o penuria de la plata, si hay mucha, andan bajos los cambios, si poca crecen, y está claro, que la abundancia, ofalta causan, se estime en mucho, o se tenga en poco. (MERCADO, 1975, p. 329).

A estimação subjetiva da moeda conforme a região justificaria os lucros nos negócios dos cambistas ${ }^{22}$, pois se para ser lícita uma transação comercial precisava ser justa (igual), era verdade, também, que uma mesma mercadoria poderia ser mais apreciada em uma regiáo do que outra. Esta diferente apreciação de uma determinada mercadoria conforme a regiáo equalizava duas coisas desiguais. Assim:

[...] una arroba de vino se precia más en una provincia que en otra. Una arroba de vino se precia mucho más sin comparación en Indias, que en España, y una de aceite, más en Flandes, que en Castilla, tanto que son iguales, una pipa de vino en México, y diez en Jerez, y se podrían trocar y cambiar lícitamente, dar una en Nueva España, por diez en Cazalla. Y dentro del mismo reino, un cesto de aceituna gordal, en Valladolid se puede cambiar, con cuatro en Manzanilla, y serian cambios y trueques jus-

\footnotetext{
22 A diferença entre usura e ganho legítimo era essencialmente a seguinte: "Que el cambio gana por la distancia y diferencia de lugares do se estima diferentemente el dinero. La usura sin pasar por estos caminos, gana por sola la necesidad del que la pide" (MERCADO, 1975, p. 332).
} 
tos, y habrian en ellos igualdad. De esta forma pasa en las monedas, que por estimarse más en una parte que en otra vienen, a ser iguales, aunque sea diversa la cantidad, noventa y tres en Flandes con ciento en Sevilla, no por ser de otra ley el ducado, ni de otro valor, sino porque la tierra de suyo lleva (como dicen) hacer más caso del dinero (MERCADO, 1975, p. 330-331, grifo nosso).

Mercado destacou ainda que em todas as mercadorias havia duas coisas distintas: a substância, ou a essência, que era algo objetivo e constante, e o valor subjetivo, acidental, que dependia da estimação das pessoas. Sendo a moeda uma mercadoria, "asi na moneda hay dos cosas, que es la una su valor y ley, lo cual es su substancia e naturaleza en ser moneda: y lo otro la estima" (MERCADO, 1975, p. 331). Se em relação à substância ou à essência da moeda havia estabilidade, no concernente à estima havia tâo somente a variabilidade. $\mathrm{E}$ ainda, nas coisas vendáveis, o valor subjetivo não seguia a natureza mesma das mercadorias e nem sua dignidade, mas "la necesidad que delas tenemos, y lo que sirve" (MERCADO, 1975, p. 331). O que o dominicano de Sevilha estava explicando era que nas trocas envolvendo dinheiro não se levava em consideração tanto sua natureza (o valor intrínseco da moeda), mas a estimação subjetiva que as pessoas atribuíam ao dinheiro. E a maior ou menor estima da moeda estavam diretamente relacionadas com sua maior ou menor oferta e circulação em determinada região. Por isso, "vemos claramente que teniendo los metales en muchas naciones el mismo precio, se estiman desigualmente" (MERCADO, 1975, p. 332).

Outro autor da Escola de Salamanca, também muito importante para a compreensão da teoria quantitativa da moeda é Juan de Mariana ${ }^{23}$ (1536-1624). De acordo com Samuel Gregg (2016, p. 74-75), de todos os autores salmantinos, Juan de Mariana foi o mais radical na crítica à intervenção dos governantes nas questôes monetárias. Mariana entendeu que os perigos advindos da política estatal de desvalorização da moeda eram não somente econômicos, mas também políticos, uma vez que a desvalorização monetária era usada como instrumento de controle social em beneficio de um governo tirânico. Em casos assim (onde os governantes lançavam mão da manipulação da moeda com finalidade política para controle social), Mariana afirmava que a justiça natural permitia o tiranicídio.

Logo no prólogo de sua obra Tratado y Discurso sobre la Moneda de Vellón, publicada em 1609, Mariana deixa claro que a motivação de seu trabalho era

${ }_{23}$ Padre jesuíta, nascido na cidade de Talavera de la Reina, perto de Toledo. Professor de teologia em Roma, Palermo e Paris, ficou famoso por defender o tiranicídio em seu livro De rege et regis institutione (1598). 
denunciar o que considerava abusos e desordens acerca "de la moneda de vellon que hoy se acuña en Castilla"24 (MARIANA, 1987, p. 27). Tais abusos e desordem eram geradores de enormes inconvenientes que afetavam a população inteira, "pues todo el reino clama y gime debajo la carga, viejos y mozoz, ricos y pobres, doctos y ignorantes" (MARIANA, 1987, p. 27). E se nem todos eram capazes de compreender as origens de seus infortúnios, a alguns era dada a capacidade de "avisar por escrito lo que anda por las plazas, y de que están llenos los rincones, los corrillos y calles" (MARIANA, 1987, p. 27). Por meio de seus escritos Mariana esperava que, diante da verdade e cumprindo com seus deveres de consciência, pudesse avisar sobre "los inconvenientes y daños que á estos reinos amenazan si no se reparan las causas" (MARIANA, 1987, p. 28). E as causas de tantos inconvenientes e ameaças ao reino da Espanha ligavam-se ao fato de sua moeda estar perdendo valor.

O primeiro capítulo do tratado de Mariana traz como título a seguinte proposição: Si el rey es señor de los bienes particulares de sus vasallos, ao que ele argumenta que o rei não é senhor dos bens de seus súditos, por isso não pode "entrar por las casas y heredamientos de sus ciudadanos y tomar y dejar lo que su voluntad fuere" (MARIANA, 1987, p. 31-32). A função do soberano, de acordo com Mariana, seria a de zelar pelo bem comum e proteger seus súditos em situação de perigo (como nas guerras), e essa função lhe daria o direito de arrecadar impostos específicos para a proteção da comunidade. Quando um governante extrapolava esse direito de arrecadação de impostos para a segurança da comunidade, ele avançava sobre o direito de propriedade de seus súditos (prática típica de caudilhos e tiranos). Sobre a diferença entre um tirano e um rei legítimo, o padre jesuíta escreveu: "El tirano es el que todo lo atropella y todo lo tiene por suyo; el rey estrecha sus codicias dentro de los términos de la razón y de la justicia, gobierna los particulares, y sus bienes no los tiene por suyos ni se apodera de ellos sino en los casos que le da el mismo derecho". (MARIANA, 1987, p.33).

Para Juan de Mariana, um rei legítimo jamais deveria impor uma tributação à sua população, "ninguna cosa puede el rey en perjuicio del pueblo sin su beneplácito, ni les podrá tomar parte de sus bienes sin él, como se hace por via de los pechos" (MARIANA, 1987, p. 36). Pois, por meio dos impostos não consentidos, "toma el principe parte de la hacienda de sus vassalos, para lo cual no tiene autoridad” (MARIANA, 1987, p.38). E, para Mariana, a política de desvalorização da

\footnotetext{
${ }^{24}$ Até o século XV a moeda de vellón era cunhada a partir de uma mistura de prata e cobre. Do século XVI em diante o conteúdo de prata da moeda foi sendo gradativamente diminuído até chegar ao ponto de ser cunhada somente em cobre. As moedas de ouro e de prata também sofreram redução de metal precioso em sua cunhagem no mesmo período, mas nenhuma outra moeda sofreu mais diminuição de seu conteúdo nobre do que a de vellón, sendo este o motivo do título do Tratado de Mariana.
} 
moeda, na prática, era um tipo de imposto que recaia sobre a população. Sendo a desvalorizaçáo da moeda uma espécie de imposto, para ser legítima precisaria da aprovação do povo, o que obviamente náo acontecia: "este arbitrio nuevo de la moneda de vellón, que si hace sin acuerdo del reino es ilícito y malo, si con el, lo tengo por errado y en muchas maneras perjudicial' (MARIANA, 1987, p. 18-19).

Mariana reconhecia o direito do rei em situaçóes de emergência (geralmente em guerras e bloqueios) de mudar o valor da moeda, mas mesmo nestas ocasiôes era necessário que a adulteração durasse o mínimo de tempo necessário e que, passada a situação emergencial, o rei restituísse "los daños á los interessados" (MARIANA, 1987, p. 39). Isso porque "el principe no es señor, sino administrador de los bienes particulares” (MARIANA, 1987, p. 40) e por nenhum caminho pode tomar os bens de seus súditos, "como se hace todas las veces que se baja la moneda, pues les dan por mas lo que vale menos” (MARIANA, 1987, p. 40). E se o príncipe não pode lançar impostos contra a vontade de seus vassalos, também náo pode adulterar o conteúdo da moeda, diminuindo seu valor real, porque "todo es quitar á los del pueblo sus bienes por mas que se les disfarce con dar mas valor legal al metal de lo que vale en si mismo" (MARIANA, 1987, p.40). Nesse sentido, a prática de alterar o valor da moeda de forma frequente (e sem verdadeira necessidade) era considerada por Mariana como típica de reis ladróes que roubam seus súditos.

De acordo com Juan de Mariana (MARIANA, 1987), na moeda existiam dois valores: um intrínseco e natural, que resultava da qualidade e do peso do metal em sua cunhagem; outro extrínseco, que era determinado pelas leis, já que os príncipes podiam estabelecer o valor da moeda, bem como das mercadorias. $\mathrm{O}$ verdadeiro uso da moeda e o que nas repúblicas bem ordenadas "se ha siempre pretendido y practicado es que estos valores vayan ajustados, porque cómo sería injusto en las demás mercadurías que lo que vale ciento se tase por diez, asi es en la moneda" (MARIANA, 1987, p. 43). No entanto, no caso da moeda de vellón a depreciação do valor intrínseco estava ocorrendo de forma escandalosa, já que em seu processo de cunhagem a qualidade e o peso dos metais nobres passavam por sucessivas reduçóes. Por exemplo, em 1497, os Reis Católicos mandavam cunhar de um marco de cobre (onde se misturavam sete gramas de prata) noventa e seis maravedis. Após um século, época em que Mariana estava escrevendo, não se mesclava nenhuma prata " $y$ de um marco de cobre se acuñan doscientos ochenta maravedis” (MARIANA, 1987, p. 45). Assim, a moeda de vellón (maravedi) experimentava uma profunda disparidade entre o valor real e o valor legal. $\mathrm{O}$ resultado dessa disparidade era a sua depreciação, uma vez que "nadie quiere dar por la moneda mas del valor intrinseco que tiene” (MARIANA, 1987, p. 45). A moeda de vellón tornou-se um dinheiro indesejado, tornou-se uma "moneda tan 
baja y tan mala, que todos la querran echar de su casa, y los que tienen las mercadurías no las querrán dar sino por mayores cuantías [de moedas]' (MARIANA, 1987, p. 71). Além disso, se o valor intrínseco da moeda é reduzido, os preços de todos os produtos irão, sem falha, aumentar na mesma proporção: "que si baja el dinero del valor legal, suben todas las mercadurías sin remedio, a la misma proporción que abajaron la moneda" (MARIANA, 1987, p. 46). Mariana constatou a partir da experiência que a redução do conteúdo de metal nobre nas moedas e o aumento de sua quantidade em circulação produziam um fenômeno que hoje é chamado de inflação, isto é, a elevação dos preços das mercadorias (é importante destacar que Mariana nunca usou a palavra inflação que era, na época, desconhecida).

Mariana constatou também que, no passado, muitos reis tentaram conter o efeito inflacionário da depreciação da moeda por meio da taxação dos preços das mercadorias, "remedio que empeoró la llaga y no se pudo llevar adelante, porque nadie queria vender" (MARIANA, 1987, p. 69), pois os comerciantes trabalham para obter lucro e não prejuízo; se a taxação das mercadorias, por meio de decretos reais, os impedem de realizar suas atividades lucrativamente, eles, simplesmente, param de comerciar. $\mathrm{O}$ resultado de tal política desastrosa foi sempre a carestia e o empobrecimento do reino todo (MARIANA, 1987). E além da carestia generalizada e do empobrecimento de todo o reino, havia outro efeito da depreciação da moeda, que era "el mayor inconveniente de todos, que es el ódio comum en que forzosamente incurrirá el principe por esta causa" (MARIANA, 1987, p. 73). Na opiniấo de Juan de Mariana, a situação econômica, social e política na Espanha só não estava ainda pior porque, apesar da depreciação do valor da moeda de vellón, a moeda de prata conservava estabilidade em seu valor.

A la verdad la moneda, y mas la de plata, por ser tan usual y tan cómoda para todo, es el fundamento verdadero de la contratación, el cual alterado, todo sin remedio se empeorará, que si estos daños no se han visto tan claros en la baja que se hizo de la moneda de vellón, fue porque la plata l ha tenido todo entrenado, que al fin por treinta y cuatro maravedis de estos malos y bajos dan un real d plata que es de buena ley; quintele este freno, y verán como en breve todo se sube y todo el comercio se embaraza. (MARIANA, 1987, p. 78).

Mariana estava convicto de que o fundamento de toda a estrutura econômica de uma sociedade era composto por peso, medida e dinheiro. E assim "como el cimiento del edificio debe ser firme y estable" (MARIANA, 1987, p. 47), também pesos, medidas e moedas deveriam ser estáveis para não confundirem e inviabilizarem todo o comércio de um povo. A fim de propor soluçôes para 
que os príncipes pudessem equilibrar suas dívidas, sem recorrerem ao nefasto artifício de adulteração do valor das moedas, Mariana (1987) escreveu sobre a importância de se evitarem as guerras, reduzirem os gastos públicos, moderarem na concessão de benefícios aos funcionários reais e extinguirem os monopólios. Além disso, Mariana também falou sobre a importância da criação de impostos sobre os artigos de luxo para o equilíbrio do orçamento público - uma medida que não afetaria os pobres e náo criaria obstáculos para o comércio em geral, uma vez que tais mercadorias não formavam a base das operaçôes comerciais.

\section{Considerações finais}

Em síntese, é possível depreender que estes pensadores estavam evidenciando que a valoração da moeda pelas pessoas (diante de sua escassez) influenciava no seu valor de troca. A utilidade da moeda, sozinha, não era a fonte do valor econômico, mas a utilidade e a escassez, juntas, determinavam o valor econômico. Tal interpretação, inevitavelmente, se antagonizava com a política mercantilista, de grande acúmulo de metais preciosos, adotada pelas coroas ibéricas na época. Para os escolásticos salmantinos estava claro que o acúmulo de metais preciosos em solo nacional por si só não significava o enriquecimento de um Estado. Mas não apenas isso. Estes teólogos perceberam que a política de acúmulo de metais preciosos, eventualmente, acarretava uma desvalorização do dinheiro e, consequentemente, o empobrecimento da população. Isto porque, para os autores da Escola de Salamanca, as fontes de riqueza nacional estavam mais ligadas ao incremento da produção e das trocas comerciais e à intensificação da vida econômica de uma determinada região. Sendo o ouro e a prata apenas os instrumentos para a viabilização das atividades comerciais, náo podiam por si mesmos gerar a riqueza de um povo (exatamente o que a Escola Fisiocrata alegará sobre o dinheiro no século XVIII). Ou seja, mais importava um comércio pujante que o mero acúmulo de metais preciosos em solo nacional para o enriquecimento de uma nação (precisamente a argumentação sobre a função do comércio usada pela Economia Política Clássica a partir do século XVIII).

Embora alguns autores qualifiquem as escritos dos escolásticos tardios como mercantilistas ${ }^{25}$, nós acreditamos que dificilmente a Escola de Salamanca poderia ser definida nestes termos, uma vez que suas ideias não estavam afinadas com aquelas encontradas entre os escritores mercantilistas, sobretudo no que concerne à teoria quantitativa da moeda. Como buscamos evidenciar, era

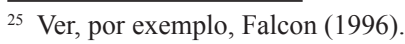


recorrente entre os autores mercantilistas a ideia de que a riqueza de uma nação dependia da quantidade de moeda em solo nacional (metalismo). Mas, como vimos neste artigo, entre os autores salmantinos não encontramos tal convicção. Pelo contrário, eles identificam o excesso de moeda com a sua desvalorização e, consequentemente, empobrecimento geral da população.

O fato de os autores da Escola de Salamanca serem contemporâneos ao sistema político e econômico mercantilista não os torna, necessariamente, parte desse movimento, por assim dizer. Em nossa interpretação, os autores salmantinos estavam mais para opositores das ideias mercantilistas, sobretudo das ideias relacionadas aos efeitos que o acúmulo de metais preciosos causava à economia nacional.

Nós não ignoramos que existe uma dificuldade enorme entre os especialistas em conceituar exatamente o sistema mercantilista. Para Falcon (1996, p. 65) "é extremamente problemático afirmar a existência dessa unidade de conteúdo ou de perspectivas a propósito dos enunciados discursivos que nos habituamos a chamar de ideias mercantilistas." Mas, se nós partimos da premissa de que a principal ideia que pôde fornecer algum ponto de unidade e coerência entre os autores mercantilistas é basicamente a defesa da balança comercial favorável, advinda de uma noção metalista, protecionista, industrialista e monopolista cuja consequência necessária foi transformar o comércio internacional numa verdadeira guerra permanente, na qual eram lícitas todas as manobras para aleijar os competidores - entấo dificilmente poderemos enquadrar a Escola de Salamanca nesta categoria.

Com a Escola de Salamanca já é possível encontrar uma visão sobre as causas do enriquecimento nacional mais afinada com o desenvolvimento comercial geral, com a circulação dos produtos e dos lucros internacionais, chegando mesmo ao que poderíamos chamar de um primeiro modelo econômico global. Nesse sentido, acreditamos que os autores da Escola de Salamanca desenvolveram uma corrente de pensamento econômico original; elaboram um conjunto de ideias sobre o funcionamento da economia que, inclusive, serviu de fundamento para o desenvolvimento de correntes do pensamento econômico posteriores, como a Escola Fisiocrata e a Economia Política Clássica.

\section{REFERÊNCIAS}

ARCE, G. Del mercantilismo a los clásicos: una introducción a las ideas económicas. Montevideo: Universidad de la República, 2013. 
AZPILCUETA, M. de. Comentario resolutorio de cambios. Madrid: Consejo Superior de Investigaciones Científicas, 1965.

BARRIENTOS, J. G. Repertorio de moral económica (1526-1670): La Escuela de Salamanca y su proyección. Pamplona: Eunsa, 2011. (Coleccion de Pensamiento Medieval y Renascentista, n. 124).

BELDA PLANS, J. Hacia una noción crítica de la "Escola da Salamanca". Scripta Theologica, Pamplona, n. 31, p. 367-411, 1999.

BERMEJO, I. J. ¿Escuela de Salamanca y Pensamiento hispánico?: Ante una propuesta. Salmanticensis, Salamanca: v.59, p. 83-114, 2012.

CHAFUEN, A. Economía y ética, Raíces cristianas de La economía de libre mercado. Madrid: Rialp, 1986.

CULLETON, A. O que é a escolástica e a Escola de Salamanca. Revista do Instituto Humanitas Unisinos, São Leopoldo, ano X, n. 342, 2010.

DEYON, P. O mercantilismo. São Paulo: Perspectiva, 1985.

DOBB, M. A evoluçáo do capitalismo. Sáo Paulo: Abril Cultural, 1983.

GÓMEZ CAMACHO, F. Origen y desarrollo de la ciencia económica: Del precio justo al precio de equilibrio. Cuadernos de Economía, Madrid, v.13, p. 477-489, 1985.

GREGG, S. For god and profit: how banking and finance can serve the common good. New York: The Crossroad Publishing Company, 2016.

GRICE-HUTCHINSON, M. El concepto de la Escuela de Salamanca: sus orígenes y su desarrollo. Revista de Historia Económica, año VII, n. 2, supl., p. 21-26, Primavera-Verano 1989.

GRICE-HUTCHINSON, M. The School of Salamanca. Oxford: Clarendon Press, 1952.

FALCON, F. J. C. Mercantilismo e transição. São Paulo: Brasiliense, 1996.

FONT DE VILLANUEVA, C. La racionalidad económica en la Escuela de Salamanca: Francisco de Vitória y Luis de Molina. In: SCHWARTZ, P. (coord.). Variaciones sobre la historia del pensamiento económico mediterráneo. Almería: Fundación Cajamar, 2006. p. 153-163. (Colección Mediterráneo Económico, v.9).

FUENTES, J. L. P. El pensamiento económico de la Escuela de Salamanca. Santa Cruz de Tenerife: Fundación Canaria Orotava de Historia de la Ciencia, 2017. 
FUERTES, J. V. La Escuela de Salamanca y José Larraz. La Ilustración liberal, Madrid, n.11, p. 91-95, 2002.

HUGON, P. História das doutrinas econômicas. São Paulo: Atlas, 1980.

MARIANA, J. de. Tratado y discurso sobre la moneda de vellón. Madrid: Instituto de Estudios Fiscales, 1987.

MARTÍN MARTÍN, V. La escuela clásica (V): la teoría monetaria: De la filosofía griega a las controversias del siglo XIX. In: PERDICES DE BLAS, L. (ed.). Historia del pensamiento Económico. Madrid: Editorial Síntesis, 2012. p. 231-262.

MERCADO, T. de. Suma de Tratos y Contratos. Madri: Nacional, 1975.

PENA GONZÁlEZ, M. A. Aproximación histórica al concepto "Escuela de Salamanca”. Salamanca: Universidad Pontificia de Salamanca, 2008.

PENA GONZÁLEZ, M. A. Aproximación histórica al concepto "Escuela de Salamanca". Salmanticensis, Salamanca, v.52, n.1, p. 69-119, 2005.

PERDICES DE BLAS, L. (ed.). Historia del pensamiento económico. Madrid: Editorial Síntesis, 2003.

QUESNAY, F. Economia. São Paulo: Ática, 1984.

REEDER, J. El pensamiento económico de los escolásticos. In: PERDICES DE BLAS, L. (ed.). Historia del pensamiento económico. Madrid: Editorial Síntesis, 2003. p. 21-41.

RIVAS, L. G. El comercio con América y los orígenes del pensamiento económico: La Escuela de Salamanca en Europa. In: PEREIRA, I. (coord.). Actas de la V Reunión Científica de la Asociación Española de la Historia Moderna. Cádiz: Servicio de publicaciones de la Universidad de Cádiz: Asociación Española de Historia Moderna, 1999. p.139-147. Tomo I: Felipe II y su tiempo.

ROOVER, R. de. Scholastic Economics: Survival and Lasting Influence from the Sixteenth Century to Adam Smith. Quarterly Journal of Economics, Cary, v. 69, n. 2, 1995 .

SANDRONI, P. (org.). Dicionário de economia. São Paulo: Ed. Best Seller, 1989.

SARANYANA, J-I. A Filosofia Medieval: das origens patrísticas à escolástica barroca. Tradução de Fernando Salles. São Paulo: Instituto Brasileiro de Filosofia e Ciência 'Raimundo Lúlio' (Ramon Llull), 2006.

SILVA, K.V. Dicionário de conceitos históricos. São Paulo: Contexto, 2006. 
SMITH, A. A Riqueza das Naçóes: Investigaçáo Sobre sua Natureza e suas Causas. São Paulo: Nova Cultural, 1996. v.1.

VILAR, P. Oro y moneda en la historia: 1450-1920. Barcelona: Ariel, 1982.

VOZMEDIANO, J. L. A. Thomas Mun y el tesoro de Inglaterra, o los orígenes intelectuales de la expansión comercial inglesa. In: HERNÁNDEZ, A. J. R. (ed.). Comercio, ejército y finanzas en una época en transición (Siglos XVII-XVIII). Valladolid: Castilla Ediciones, 2017. p.385-402.

ZORROZA, M. I. Hacia una delimitación de la Escuela de Salamanca. Revista Empresa y Humanismo, Pamplona, v. 16, n. 1, p. 53-72, 2013.

Recebido em: 17 de maio de 2021.

Aprovado em: 21 de setembro de 2021. 